\title{
The Misunderstandings and Teaching Strategies on English Grammar Learning in College
}

\author{
SHI Xi-chun, CHEN Meng-jie \\ Changchun University, Changchun, China
}

\begin{abstract}
English grammar teaching in college is a very challenging task, because teachers must not only consider the increase of students' communicative competence, but also take care of their grammar knowledge learning in the teaching process. This paper puts forward three teaching countermeasures based on the English grammar learning misunderstanding of college students, namely strengthen the grammar study of psychological counseling, strengthen guidance for English grammar learning method, and choose the teaching method of combination of explicit grammar and implicit grammar teaching.
\end{abstract}

Keywords: college English, grammar, misunderstanding

\section{Introduction}

People hear in daily life environment most is Chinese instead of English in China; Chinese students lack environment where they can put themselves into English language. What is more, the structure of the Chinese is greatly different from that of English; it is very difficult to naturally occur on Chinese students in the natural acquisition of English grammar. In view of this, it is very important and necessary for English grammar teaching to improve students' communicative competence, especially the written communication skills, which should occupy a certain position and proportion in college English teaching.

\section{College Students English Grammar Learning Misunderstanding and Correlation Analysis}

The importance of English grammar in college English learning has undergone a process from important to rational. In the public English teaching in college, teachers often run into two cases reflected by some freshmen: One is that the college English grammar is more than that of middle school; the other is that college English grammar is more difficult than that of high school. The reason why they reflect the two cases above is that their scoring average on grammar, translation, and writing in A and B level test, CET-4 (College English Test Band 4) and CET-6 (College English Test Band 6) is generally low. In order to make their score improved, some students ask teachers whether they can give them systematical teaching in public English class from word to sentence, from sentence to paragraph, and from section to piece. Facing the two conditions and the demands of students, as a college English teacher, people have to give students an explanation or make a claim.

SHI Xi-chun, lecturer, master, Public Foreign Language Teaching and Research Department, Changchun University. CHEN Meng-jie, lecturer, master, Public Foreign Language Teaching and Research Department, Changchun University. 


\section{The View of College English Grammar Is More Difficult and Not Exact}

People can see from the actual experience of college English grammar teaching, the two situations students reflect are not exact. Because it can be realized that when people are in college English grammar teaching, teachers do not teach students new grammar knowledge, just some grammars which are not arbitrarily demanded for students to master in middle school English teaching, such as future perfect progressive; this tense also be mentioned and studied in middle school, so it is not a new content. English grammar in college has been studied in middle school, so there should be no view that the number of college English grammar is more than that of middle school. The difference between them is that the vocabulary required to master in the university is more, thus increasing the number of terms and relevant collocation, which is of course for college students. The other case that college English grammar is more difficult than high school is not accurate either, because we are taught the same grammar in college with middle school. There may be some differences in the vocabulary required to master in the university, as well as the irregular past tense and past participle, and severe closed syllable words. All of the above require students' wide range of words, which will burden students heavily. But in turn, people should think of it that since the student has become a college student, how they can also use high school requirements for college. The problem seems like a comparison between calculus of university and algebra equation in high school. It is likely that the calculus of university is more difficult on the surface, but the subject of learning the content has changed: One kind is university students, and another is middle school students. The school age level and knowledge structure of students have improved. Is it suitable for students to continue to learn knowledge of lower level and narrow range, such as the English grammar taught in junior middle school? Therefore, even if the content in university English grammar is more difficult than that of middle school, it is also perfectly acceptable for this school stage of learning of college students.

\section{Extreme Difficulty in the Grammar Teaching of Words-Sentence-Section-Piece}

There are different ways in college English grammar teaching, but these ways must be combined with the actual college English teaching. As said earlier, college English teachers are faced with the situation of time tight and task heavy, which almost cannot satisfy the requirement of students for "words-words-section- piece" grammar teaching. The author learns from the English professor that they teach English grammar two classes per week, which just barely finish all of the content in a semester, and most of them are finished by students' reading the master themselves. There are some differences between students learning college English and English major students in vocabulary and English basic. Generally speaking, English major students are much better than non-English major students in vocabulary and English basic. When given the grammar teaching of "words-words-section-piece", it is hard for students learning English to complete such a system of English grammar teaching in a semester. In that case, what to do with the teaching task of public English? Besides, it also does not conform to the current of the request of "college English syllabus".

\section{Teaching Countermeasures to College English Grammar Learning Cognition}

\section{Strengthen the Psychological Counseling in Grammar Learning}

There exists inexactness in the situations and requirements put forward by students, but it is also understandable. The reason why they put forward such views is that they are eager to learn English, and it is a normal psychological reaction when faced with the low scoring average in translation, writing, and translation. 
At this time, the teacher must deal well with the psychological counseling for students to overcome their low emotions and pessimistic attitude during English learning. At the same time, teachers should also help students to cultivate their self-confidence in English grammar learning. Teachers can directly tell them English grammar is not difficult to learn and they can learn English grammar well as long as they learn seriously and carefully. By this case, they will not only learn English grammar well, but also the English language. English is not the patent of English major students; he belongs to the people all over the world. Non-English major students also can speak fluent and idiomatic English as English major students as long as they learn by heart. There are some non-English major students in daily life whose English is very well; people should make them as the learning model. There is no conflict between college English grammar and middle school's; they are in a same line. Teachers should encourage students to improve their communication ability in the teaching process, and express language accurately as possible. Students can achieve the double-win to both fluency and accuracy as long as they make serious efforts in learning.

\section{Strengthen Guidance to English Grammar Learning Method}

For college English grammar learning, the learning effect of a lot of students is not good, the reason of which is not their limited work, but their wrong method. Grammar is the rules of the change of the word or making words a sentence, and students should apply suitable ways when learning. It takes too much time for non-English major college students to use the grammar learning of "word-words-section-piece" mentioned above, and at the same time, there is no need for such a detailed learning process. People can try such a learning sequence which is relative systematic if they want to study English grammar well: (1) Understand basically the word category and word character of English vocabulary, and what ingredients these words can generally act in the sentence; (2) Learn the five basic sentence patterns of English; (3) Learn the tenses and its variants, such as the expression of certain, negative, and question sentence; (4) Learn the passive voice consistent with the tenses and its variants, such as the expression of certain, negative, and question sentence; (5) Learn clauses; (6) Learn the predicate verb; and (7) Learn the subjunctive mood. Students should pay attention to the form expression of structure, time adverbial, and special usages when learning tense, voice, and subjunctive mood. Many students do not pay attention to the aspect of the reinforcement learning when they study tense, voice, and subjunctive mood, which results in poor learning effect. While learning English grammar, students should combine with the usual communication practice, translation practice, writing exercises, homework, and even extracurricular English activities, and make grammatical mistakes or make no grammar mistakes as less as possible in these exercises and activities. As long as after a long practice and use of English grammar, it will naturally become the habit of students to use English, and make less grammar mistakes.

\section{Choose the Teaching Methods Combing Explicit Grammar Instruction With Implicit Grammar Teaching}

College English teaching emphasizes the learners' language communicative competence at present, so the communicative approach is more popular. The use of communicative approach in English grammar usually makes students learn grammar knowledge and induces the rules of sentence patterns use in the form of natural acquisition through the context of meaningful communication activities; this teaching method is often referred to as the implicit grammar teaching grammar. The teaching method above has the advantage of students' access 
to the meaningful language material, which will strengthen the ability of using language of students, especially the oral communication ability. However, students' English grammar rules are not clearly instructed and introduced; students' consciousness on grammar is not high, but centers on the pragmatic aspects of language level, so students lack systematic study of grammar. Nowdays, some scholars advocate explicit grammar teaching, which refers to the method achieving the objective of the master grammar teaching through the grammar structure teaching directed by teachers and conscious pattern practice of students. The advantage of explicit grammar teaching is that students can clearly know the rules of grammar which will strengthen students' awareness of grammar. Therefore, teachers can choose according to the characteristics of the grammar in the college English grammar teaching. When the grammar point is difficult, teachers can choose the way of explicit grammar teaching to clearly explain grammar rules, thus students are easier to understand the grammar; when the grammar knowledge is not difficult, teachers should use the way of implicit grammar teaching to make students sum up the rules of sentence patterns, which will achieve a economic use of time, as well as the balanced development of the two aspects of language ability and communication skills.

\section{Conclusion}

To sum up, college English grammar in English teaching should possess the corresponding position, so as to cultivate the students' written communication skills. It is possible to solve the situation students reflect when strengthen students' psychological counseling of grammar learning and guidance to English grammar learning method in college English teaching. At the same time, teachers should also choose the teaching methods of combination of the explicit grammar and implicit grammar teaching. In this way, students can also get to learn, consolidate, and improve a relatively systematic grammar.

\section{References}

GAO, Y. (2007). Strengthen the consciousness of syntax and grammar teaching. Foreign Language World, 158(6), 147-148.

LI, J. (2004). Theory of classroom teaching target expression. Journal of Longdong Institute, 63(14), 34-35.

LONG, X. P., \& LIU, X. Q. (2007). Survey of college students' English grammar learning and its enlightenment to grammar teaching. Foreign Language and Foreign Language Teaching, 28-30.

LUO, H. B., TAN, L. Q., \& YANG, Y. Y. (2009). Introduction to the application of task-based teaching in college English grammar teaching. Journal of Pingxiang College, 26(9), 57-60.

TANG, Z. X. (2006). Survey and suggested about vocational education development in hunan province. Contemporary Education $B B S, 98(7), 224$.

YANG, D., \& LI, M. Y. (2009). Task-based teaching method in college English grammar teaching in practice. Journal of Shenyang Institute of Education, 67(3), 51-54.

YANG, S. J. (2007). The importance of college English grammar teaching and classroom teaching mode. Jiangsu Foreign Language Teaching Research, 47(22), 23-27.

ZHAO, C. Y. (2009). Overall teaching strategy of college English grammar. China's Adult Education, 123(4), 157-158. 